\title{
ICTS's knowledge work and employment: The challenges to Europe
}

Citation for published version (APA):

Soete, L. L. G. (2001). ICTS's knowledge work and employment: The challenges to Europe. International Labour Review, 140(2), 142-163. https://doi.org/10.1111/j.1564-913X.2001.tb00218.x

Document status and date:

Published: 01/01/2001

DOI:

10.1111/j.1564-913X.2001.tb00218.x

Document Version:

Publisher's PDF, also known as Version of record

\section{Please check the document version of this publication:}

- A submitted manuscript is the version of the article upon submission and before peer-review. There can be important differences between the submitted version and the official published version of record.

People interested in the research are advised to contact the author for the final version of the publication, or visit the DOI to the publisher's website.

- The final author version and the galley proof are versions of the publication after peer review.

- The final published version features the final layout of the paper including the volume, issue and page numbers.

Link to publication

\footnotetext{
General rights rights.

- You may freely distribute the URL identifying the publication in the public portal. please follow below link for the End User Agreement:

www.umlib.nl/taverne-license

Take down policy

If you believe that this document breaches copyright please contact us at:

repository@maastrichtuniversity.nl

providing details and we will investigate your claim.
}

Copyright and moral rights for the publications made accessible in the public portal are retained by the authors and/or other copyright owners and it is a condition of accessing publications that users recognise and abide by the legal requirements associated with these

- Users may download and print one copy of any publication from the public portal for the purpose of private study or research.

- You may not further distribute the material or use it for any profit-making activity or commercial gain

If the publication is distributed under the terms of Article $25 \mathrm{fa}$ of the Dutch Copyright Act, indicated by the "Taverne" license above, 


\section{ICTs, knowledge work and employment: The challenges to Europe}

\section{LUc SOETE*}

hat new information and communication technologies (ICTs) are 1 important for growth and employment is now a matter of broad consensus in policy-making, business and also, increasingly, academic economics. The consensus appears to be based on three specific features of these technologies that have been instrumental in bringing about fundamental, structural transformations in the economic, social and organizational framework of society, opening up an increasing number of sectors to international exchange, competition and restructuring. Firstly, there has been the dramatic reduction in the cost of digital information and communication processing, a process of technological improvement that has not shown any sign of decreasing returns and is unlikely to do so in the near future. This continuous reduction in costs has been behind a sustained upgrading in the performance of ICTs and the steady expansion of their applications. Secondly, there has been the technologically driven "digital convergence" between communication and computer technology, between individual person-to-person communication systems — such as the telephone - and broadband, "one-to-many" information and telecommunications systems such as radio and television - which is rendering feasible any combination of communication forms. Thirdly, there has been the rapid growth in international electronic networking, whether terrestrial or through satellites the world as a village. This effectively makes ICTs the first global technological transformation, hence the reference to ICTs as the "biggest ever juggernaut" (Freeman and Soete, 1994), a process of technological and economic transformation historically unprecedented.

These features of transformation affect all aspects of society. First, they are by no means confined to the manufacturing and distribution of goods and services, even though the economic transformation they are bringing about

* MERIT, University of Maastricht, The Netherlands. This article is based on a background paper prepared for the ILO's World Employment Report 2001: Life at work in the information economy. 
might be most visible in those traditional sectors. Indeed, they primarily affect communication between individuals, between organizations whether they are formally structured (as in the case of firms) or consist of informal, virtually organized "communities" - and increasingly, of course, between individuals and machines. Second, they effectively render physical space and distance irrelevant and therefore question institutional or administrative boundaries, whether regional, national or even supranational, such as those of large trade blocks and economic or even monetary unions (e.g. the European Monetary Union (EMU)). It is in this sense that one may speak of the emergence of a "new" economy which raises fundamental new policy challenges (Petit and Soete, forthcoming).

In retrospect, the 1990s might well be characterized as a period of major structural transformation which, though clearly connected with ICTs, goes well beyond their mere appearance and diffusion. This applies to the world as a whole, but especially to Europe. For example, the early 1990s witnessed the sudden collapse of the centrally planned economies of eastern Europe and their rapid opening up to market-led incentives, the most extreme case being the economic and political integration of the former German Democratic Republic into Germany and the European Union. A year later, the 15 Member States formally set up the European Single Market. In many, non-manufacturing utilities and service sectors, this process of economic integration is still incomplete but it has nevertheless brought about a gradual opening-up of many, traditionally closed, domestic markets. Less precise in timing, but progressing at an accelerating rate, has been the dramatic, worldwide deregulation of financial markets. Independent domestic monetary policy has become a thing of the past.

More recently, the European telecommunications sector has been deregulated and liberalized as well. The resulting growth in telecom services and their increasing variety have been such that, at least up to now - and contrary to most forecasts and predictions - there have been no overall job losses in the telecom sector, rather the opposite. And finally, there was of course the macroeconomic convergence process leading to monetary union, with the formal introduction of the Euro on 1 January 1999 in 11 Member States of the European Union.

Structural transformation processes such as those concerning financial markets or even the telecom liberalization process have mostly been global. Yet they have involved certain regions or areas more than others. While Europe appears to have been at the centre of most of the structural transformations mentioned above, it has, as yet, benefited the least from the growth opportunities behind those processes. At least until recently, this has been particularly true of some of the larger Member States of the European Union. Many of the smaller European economies (e.g. Denmark, Finland, Ireland, the Netherlands, Portugal) actually witnessed remarkable growth and employment performances during the 1990s. Because their existing economic structures were already open, these smaller countries appear to have 
been better equipped to respond, adapt and learn from the structural challenges brought about by both European integration and worldwide structural transformations. Their policy-makers were apparently more aware of the international implications and inherent limitations of their policy actions. This awareness of increasingly limited freedom of policy action — with respect to both the European Union and the global economy - was also successfully conveyed to the public at large and to the local business communities. In many of the large European countries, by contrast, such reduced freedom of action proved more difficult for policy-makers to accept, as it often came into conflict with the previous, relatively strong emphasis on national identity and the relative importance of the country's international policy role.

At the same time, the worldwide structural transformation processes have also been raising fundamental questions with respect to Europe's own integration process. In some areas the carefully planned integration process appears to have been overtaken - in purpose and speed of implementation - by the broader process of worldwide integration. There could even be cases of "costs to Europe", with the European integration process effectively implying a diversion (rather than creation) of new trade, information and communication flows: European integration proceeding at the expense of global integration. It has been argued elsewhere that this process of European "cocooning" has been responsible for the loss in global competitiveness of European firms in some of the most technology-intensive sectors, such as ICTs (Soete, 1996). Of course, Europe's trade and monetary integration coincided with the rapid, global emergence and diffusion of a class of "new", digital ICTs.

This article analyses the "new" institutional policy challenges that these various structural transformations are raising for individual Member States of the European Union and for the Union as a whole. It does not elaborate on any empirical evidence, but the interested reader is referred to the claim made in our submission to the Portuguese presidency of the Union in 2000 (Soete, 2001) - that these transformations are behind the relative economic success of the United States over the 1990s. According to recent evidence, the so-called "Goldilocks scenario" of the 1990s in the United States - combining high GDP growth, low inflation and, more recently, high labour productivity with a general widening of the employment base (today also including low-skilled workers) - appears increasingly related to the diffusion of new ICTs (Oliner and Sichel, 2000; Scarpetta et al., 2000; OECD, 2000).

Before discussing these policy challenges, the article will briefly review in a first section the technology-and-employment debate. While this is an old and relatively well-known debate, it is nevertheless useful to put it into historical perspective in order to highlight the analytical restrictiveness of traditional "general equilibrium", incremental approaches to technology with respect to its likely impact on growth and employment. The argument made here - and by many others - is that the present debate surrounding 
the emerging "new economy" — the "knowledge-driven", "learning" or "knowledge-based" economy or "information society" — signals the fact that the widespread diffusion of new ICTs is indeed ushering society into an entirely new or "post-industrial" era. The latter development, as will be argued in the second section of this article, should be the starting point for any understanding of the nature of the structural transformation ICT is bringing about in our economies. The impact of ICT on the traditional industrial and industrially dependent service sectors (transport, trade and distribution of material goods) is fundamentally different from its impact on "pure" service activities. The third and fourth sections argue that this implies a continuous shift in value added, away from material production and handling towards immaterial content. The implications for employment growth and displacement are fundamental. As argued in the final section of this article they lie behind the employment and labour market challenges of the new economy.

\section{Technology, growth and employment: What's new?}

The relationship between technology, growth and employment has been the subject of many contributions in economics. ${ }^{1}$ Though controversial and hotly debated over the past two centuries, the relationship now appears straightforward, at least from the macroeconomic perspective. Either the introduction of new technologies leads to more efficient production processes, reducing costs by saving on labour, capital, materials, energy or any other factor of production, or it leads more directly to the development of new products that generate new demand. In either case, more welfare is created:

${ }^{1}$ There is now a voluminous empirical and theoretical literature on this subject. In the twentieth century alone, there have been four distinct economic debates on the relationship between technology and employment. The first, probably the most "classical" in its origins, took place during the economic depression of the 1930s. Contributors included Hansen (1931), Weintraub (1937) and Neisser (1942). Many of the issues and concerns raised by these authors sound quite familiar today, particularly in the context of the notion of increasing returns in current "new" growth models (e.g. Aghion and Howitt, 1992). The second debate focused mainly on the post-war United States and the fear of "automation". In the 1960s, levels of unemployment were higher in the United States than in Europe, and many blamed technological change. As a result, a National Commission on Automation was appointed and produced a massive six-volume report (US National Commission, 1966). This debate had little influence in Japan and in the European countries that were rapidly catching up. The third debate, which began in the late 1970s, was particularly active in Europe. It focused on the emergence of the cluster of computer-based communication, information and automation techniques associated with microelectronics, which appeared at first glance to have great labourdisplacing implications (e.g. Freeman, Clark and Soete, 1982; OECD, 1982; Katsoulacos, 1984). The fear that these displacement effects might dominate the compensating job-creation effects for quite some time recalled the classical debate in many ways. As then, it appeared to be a reflection of the times: there was a set of "revolutionary" new technologies and persisting high unemployment. The most recent upsurge focuses much more on the global aspects of the new ICTs and the possible erosion of employment and high living standards in the advanced countries. Originating to some extent in the United States, and linked to the political debate surrounding NAFTA, it quickly "globalized", and contributions have come from all over the world. 
in the first, through more efficient production combinations that liberate scarce input resources; in the second, by satisfying new wants.

The extent to which this higher welfare or increased productivity feeds back into employment growth depends on the extent to which firms translate productivity gains into lower prices and new investment and the extent to which consumers respond to lower prices in terms of greater demand. The job losses that often follow the introduction of a new labour-saving process, for example, are compensated by the job creation associated with the output growth following the decline in prices, by additional employment creation in other sectors - particularly the new technology-supplying sector — and by the possible substitution of labour for capital following the downward wage adjustment that clears the labour market.

However, the extent to which new or improved products generate new employment growth depends on whether old products are replaced by new ones and on the responsiveness of consumers to the new or improved goods or services (as reflected in the income elasticity of demand). As long as there are unsatisfied needs in the economy and as long as labour and product markets are sufficiently flexible, technological change, even in the form of new labour-saving production processes, does not reduce aggregate employment but generates more growth and jobs.

Most of the controversies that have dominated the economics literature on this issue over the last decades have centred on the automatic nature of the various compensation effects described above. Many contributions have questioned the way in which cost reductions following the introduction of new technologies effectively translate into lower prices and may lead to more output growth: the functioning and flexibility of product markets depend in part on the firm's monopoly power, economies of scale and various other factors influencing "price stickiness". Similar issues can be raised with respect to employment growth and the functioning of labour markets; they range from downward wage flexibility to the many mismatches typical of relatively heterogeneous labour markets. In either case, it is less technology that is at the centre of the debate than the responsiveness and clearing function of the product and labour markets. ${ }^{2}$ The relevant policy issues fall primarily into the category of improvements in the functioning of labour and/or product markets. ${ }^{3}$

Other contributions in the classical economics tradition have questioned the possibility of ex post substitutions between labour and other factors of production. At least in the short term, the implications of a more rigid, fixed

${ }^{2}$ As Von Mises put it: "Lack of wages would be a better term than lack of employment, for what the unemployed person misses is not work but the remuneration of work. The point [is] not that the 'unemployed' [cannot] find work, but that they [are] not willing to work at the wages they [can] get in the labour market for the particular work they [are] able and willing to perform" (1936, p. 485).

${ }^{3}$ The OECD Jobs Study (OECD, 1994a, 1994b) can be said to have focused primarily on these market issues, emphasizing the functioning of labour markets. 
set of production coefficients for analysing technical change and employment are relatively straightforward. Labour-saving technological change embodied in new investment could, if wages adjust slowly, lead to unemployment because of insufficient investment to maintain the full-employment capital stock; ${ }^{4}$ this is the so-called "capital-shortage" unemployment." There was a lively debate during the 1980 s on the extent to which the increase in unemployment in European countries in the 1970 s could have been due to this phenomenon.

Yet other contributions question the automatic nature of the link between input-saving new technologies and productivity gains. Most of these studies - which often attempt to explain the "productivity paradox" - are empirical in focus and attempt to find reasonable explanations for the disappointing productivity growth of most OECD countries over the past two decades, despite rapid growth in knowledge investment - particularly in private-sector R\&D - and the emergence of the new cluster of ICTs. ${ }^{6}$ However, the discussion is far from over. In particular, there have recently been a large number of empirical and theoretical contributions from growth economists (e.g. Young, 1995; Mankiw, 1995; Soete and Ter Weel, 1999; Jones, 1999).

Finally, some recent contributions have focused explicitly on the international "open economy" framework within which most compensation mechanisms are likely to operate. As a result, the relatively straightforward linkages between technology, productivity growth and job creation mentioned above appear much more complex. A relatively simple elaboration in terms of employment compensation due to foreign demand - e.g. through export and import elasticities - complicates the matter greatly (Stoneman, 1984). More complete pictures including not only trade but also the effects of international spill-overs of technology on productivity growth (OECD, 1999) or international capital mobility (Turnovsky, 2000) make it much more difficult to identify the key links between the introduction of a new technology and the ensuing domestic employment impact.

Many of the recent concerns about the implications of technological change for employment appear to relate to these international compensation

${ }^{4}$ This result is obtained by Venables (1985), for instance, with the use of a general equilibrium setting with fixed coefficients.

5 Capital-shortage unemployment reflects an apparent lack of "productive" capital to employ part of an adequately skilled and suitably located labour force. Capital-shortage unemployment can occur as a result either of lack of physical capacity or of economic obsolescence; if variable costs exceed price, capital will not be used (and the corresponding jobs will disappear) even though such capacity could be operated in a physical sense.

${ }^{6}$ This issue was addressed in some detail in Freeman and Soete (1985 and 1993); see also OECD (1996). 
mechanisms and to the way that gains from technological change are distributed internationally. In the gloomy vision of some popular authors, ${ }^{7}$ wages in the most advanced economies are being eroded owing to the emergence of a global market-place where low-paid workers compete for the few jobs created by footloose global corporations (Rifkin, 1995). In other words, the globalization of industry and, increasingly, of services casts a new light on the interaction between technology and employment in an open economic framework characterized by low transport and communication costs.

It is still generally agreed that, in a "world" economic framework, inputsaving technological change leads - through increases in productivity - to higher welfare, wages and growth and thus generates new employment. But the impact on individual countries is now much more complex because it depends on a broad range of macroeconomic and microeconomic adjustment mechanisms. In particular, positive and negative effects do not coincide either in time or in space: adjustment takes time, and the industries and types of workers that will benefit from technological change are different from those adversely affected by it.

At the same time, the premium placed on the role of knowledge and on the acquisition of skills in this global environment implies that international differences in the pattern of employment and unemployment in industrialized economies may be coming to depend increasingly on the capacity of national economies to innovate, enter new, unregulated "service" areas and/or absorb new technology more rapidly.

\section{The information society: A move towards a post-industrial society?}

The analysis can usefully be set within a somewhat broader historical framework, going back to the emergence of the concept of the "information society". Contrary to common belief, the notion of an "information society"

${ }^{7}$ See, for example, Aronowitz and DiFazio (1994) and Rifkin (1995). As noted by some trade economists (Krugman and Venables, 1994), such views are in many ways reminiscent of the old Prebisch-Singer dependencia arguments, but applied to the advanced countries. In the old coreperiphery models, "immiserising" growth would take place in the developing countries because all the benefits of increased efficiency gains in the production of raw materials, agriculture and labourintensive manufacturing are passed on to the advanced economies, e.g. through lower prices or higher repatriated profits. In the current view, the pattern is the opposite: most of the benefits of technological change are passed on to some of the rapidly industrializing countries through more rapid international diffusion of technology from the advanced countries, the reinvestment of profits and relocation of production to those industrializing countries and the erosion of various monopoly rents in the advanced countries, including wages. In principle though, and in contrast to the PrebischSinger model, such a redistribution process should lead, as trade theory would predict, to the convergence of growth and income. 
is not new. Its origins date back to the earlier concept of a "post-industrial society" and subsequent recognition of the importance of "information technology" in speeding up the process of industrial transformation (see Porat, 1977). The rediscovery of the concept of "information society" today is in the first instance inspired by the sustained speed of technological improvement (historically unprecedented) and the extraordinary pervasiveness of ICTs (see Freeman and Soete, 1985 and 1993).

The dramatically increased capacity to store, process and disseminate information at minimal cost has been described most extensively in the context of industrial (or agricultural) production processes. Pre-dating even the early "information technology" literature, the so-called "automation debate", popular in the United States in the mid-1960s, described how labour-saving "robotics" would raise industrial productivity and bring about major organizational changes. In line with this literature, many analysts have always wondered how, confronted with such pervasive cost-reducing technologies, economies would be able to generate sufficient new employment (the various price and substitution elasticities being too low to bring about sufficient employment compensation ${ }^{8}$ ). More recently, the specific impact of new information technology on services has re-entered this debate. It could indeed be argued that the impact on services may be the opposite of what it is on manufacturing.

In many ways, services can be defined as those activities (sectors) where output is essentially consumed when produced. ${ }^{9}$ While this might well be considered a rather narrow definition and one which covers only a limited number of the sectors now falling within the statistical definition of service sectors, it is an analytically useful definition because it highlights the intrinsic immaterial, intangible nature of many service activities, be they personal services (e.g. hair-cutting), entertainment (e.g. an opera performance), education (e.g. teaching), health (e.g. a doctor's visit) or public services, such as applying for welfare services. It is this similarity centring on production and consumption which has generally limited productivity improvements in such activities. Incidentally, this also provides an intellectual argument as to why the economics profession has generally tended to ignore the study and analysis of service activities.

Almost by definition, ICTs allow for the increased tradability of service activities, particularly those which have been most constrained by the geographical or temporal proximity of production and consumption. By bringing

${ }^{8}$ Interestingly, this is also the main argument of those studies which limit their focus to manufacturing (Pianta, 1995; Reati, 1995).

${ }^{9}$ For early analyses along these lines, see Quinn (1986) and Soete (1987). 
in a space or time/storage dimension, information technology will make possible the separation of production from consumption in a large number of such activities, thereby increasing opportunities for trade in them. ${ }^{10}$

In the case of today's "new" ICTs - and their potential not just to collect, store, process and diffuse enormous quantities of information at minimal cost, but also to network, interact and communicate across the world as a "global village" — both the time/storage and space dimensions are likely to bring about further opening-up of many service activities, increasing their domestic and international tradability. As in the case of the telephone, it is likely that the "new" emerging computing and electronics manufacturing sector will in the end remain relatively small as compared with the growth and size of new information and communication service sectors. However, even the definition of the latter will become blurred as more and more of the traditional "physically present" service activities become "info-type" service activities.

With regard to more traditional production processes - typical of industrial production, but also common in traditional service sectors such as transport, wholesale and retail trade - the impact of ICTs could well be characterized as being exactly of the opposite kind. Rather than bringing time/storage between production and consumption as in services, ICTs will in the first instance aim at reducing the time/storage dimension between production and consumption. Many of the most distinctive characteristics of the new ICTs relate directly to their potential for linking up networks of component and material suppliers, thus allowing for reductions in storage and production-time costs - as typified in the so-called just-in-time production system. At the same time, the increased flexibility associated with the new technology allows for a closer integration of production with demand, thus reducing the firm's own storage and inventory costs - which could be typified as just-in-time selling. Both features clearly work in the opposite direction from that described above, i.e. they aim at reducing the time/storage dimension between production and consumption. In doing so, they might well reduce the "tradability" of a number of those intermediary storage and inventory activities.

In essence therefore, ICTs are making services more tradable and more like manufacturing, leading to a further convergence of industrial and service activities. With the growing convergence between manufacturing and services, service activities — which average some two-thirds of economic

10 This was certainly the case with regard to the invention of printing in the Middle Ages and the impact this first new information technology had on the limited tradable "service" activity of monks copying manuscripts by hand. It was the time/storage dimension of the new printing technology that opened up access to information in the most dramatic and pervasive way and led, to use Marx's words, to the "renaissance of science", the growth of universities, education, libraries, the spreading of culture, etc. This opening-up, "tradability" effect proved to be of far greater importance to the future growth and development of Western society than the emergence of a new, in this case purely manufacture-based, printing industry. 
activity in the European Union - appear to be increasingly important in their own right and, in a growing number of areas, to be dominating manufacturing rather than the other way round. Particularly since the advent of ICTs and their "tradability" impact on many service activities, the latter have emerged as "core" value-adding activities. It is essential in this context to distinguish between data and information and knowledge.

ICTs play an essential role in the "codification" of knowledge. This involves the transformation of knowledge into "information" which can either be embodied in new material goods (e.g. machines or new consumer goods) or be easily transmitted through information infrastructures. It is a process of reduction and conversion which renders the embodiment or transmission, verification, storage and reproduction of knowledge especially easy (see, in particular, David and Foray, 1995). In contrast with codified knowledge, tacit knowledge refers to knowledge which cannot be easily transferred because it has not been stated in an explicit form. One important kind of tacit knowledge is skills. The skilled person follows rules which are not known as such by the person following them. They are linked to activities mastered through learning, but often of a non-routine kind. ${ }^{11}$ The most important impact of new ICTs is that they move the border between tacit and codified knowledge. They make it technically possible and economically attractive to codify kinds of knowledge which have so far remained tacit.

The embodiment of codified knowledge in material goods has been typical of the dramatically increased performance of many new capital and consumer goods, incorporating many new electronic information and communication devices. The latter in turn have been at the core of the continuous growth of productivity, investment and consumer demand in advanced industrialized societies. As emphasized by authors criticizing the early "postindustrial society" literature, ${ }^{12}$ this process could also be described as a process of "industrialization" of services: the continuous replacement of particular service activities by material household goods, embodying at least the "codified" knowledge component (e.g. washing machines, television, dryers, etc.). The more recent electronic improvements in these products have further enhanced their "household" performance, freeing further household time. While the quality of these new material goods will not always substitute for that of the service activity they replace (a dishwasher is a good example), the codification process will be to some extent complete. The product might lack user friendliness (a typical example being the video player), but the user is not required to possess, or to understand, all the knowledge embodied in the machine.

In services, by contrast and following the arguments set out above, while the codification of knowledge will make some knowledge more widely accessible to economic sectors and agents through information networks, its

11 One might think of such activities as gardening, biking or housekeeping.

12 See, for example, Gershuny (1978) and Gershuny and Miles (1982). 
immaterial nature implies that the codification itself will never be complete. Indeed, the codification process will even rarely reduce the relative importance of tacit knowledge in the form of, say, skills or competencies, rather the contrary. And it is precisely those activities drawing on tacit knowledge which will embody the main value of the service activity: the "content". While part of the latter might be based on "pure tacitness", such as talent or creativity, the largest part will be greatly dependent on continuous accumulation of new knowledge - learning — which, in turn, will typically be based on the spiral movement whereby tacit knowledge is transformed into codified knowledge, and new kinds of tacit knowledge are then developed from close interaction with the new piece of codified knowledge. Such a spiral movement is at the very core of individual as well as organizational learning.

This continuous shift in value from manufactured goods embodying increasing amounts of "codifiable" knowledge towards service-based "tacit" knowledge activities is typical of the new, emerging information society. It explains the attempts of electronic and computer manufacturing firms to enter information content activities. Within services, it explains the move of "carrier" operating firms - being those most directly confronted with the codification of knowledge and its distribution - to enter content sectors (media, education, culture).

In other words, the emerging information society will become critically dependent on user demand for new information products and services. The "demand articulation" of the latter depends crucially on the existing regulatory, institutional framework as well as on the overall macroeconomic climate. Much has been written about the former. Many studies point to (over)regulation of a number of typical "information society" service sectors in Europe, such as multimedia, which prevents these markets from emerging more rapidly. The emergence of new service markets involves, practically by definition, new regulatory frameworks. In many typical cases of information or communication services, commercial success critically depends on the reaping of substantial economies of scale from network activities, with marginal costs being a fraction of fixed costs (one may think of movies, software, financial and insurance services, etc.). Europe, with its fragmented national markets and cultural diversity, is clearly at a disadvantage in reaping such economies of scale.

\section{The new employment challenges}

The particular employment concerns associated with the emerging information society relate primarily to the likely impact of ICTs on productivity growth and output growth, particularly in some of the new informationservice sectors described above. Much will depend on the new needs and markets those service sectors are capable of addressing; but much will also depend on the way productivity gains get redistributed throughout the economy. These gains are based as much on the overall counter-inflationary effects of 
falling costs and prices in microelectronics, computers and telecommunications which are affecting a widening range of products and services, as they are on organizational improvements and other more dynamic, learning-based efficiency improvements at the shop-floor level, in production planning or in administrative activities.

In attempting to assess the employment creation and destruction effects of ICTs, it is therefore no longer possible to distinguish many of the direct negative and positive effects from the indirect effects. The direct effects include both the creation of new jobs to produce and deliver new products and services, and the replacement of old jobs by new ICT equipment. The indirect effects comprise the many positive and negative consequences elsewhere. Thus, while computer terminals are everywhere, it is not always clear whether they are displacing workers or generating additional services and employment. The computer industry itself produced machines which displaced earlier types of electro-mechanical office equipment, while the microelectronic industry largely displaced the old valve (tube) industry. Today's digital telephone exchanges require far less labour to manufacture and to maintain than did the old electro-mechanical exchanges, and the number of people working in the telephone switchboard industry has fallen in most industrialized countries. Competitive restructuring of the old monopolistic networks has also resulted in a reduction of the number of employers, even though the number of firms and the number of lines and cells has increased. However, the new telecommunication infrastructure provides the basis for numerous new information service industries and equipment, such as e-commerce, mobile communication, Internet access, content industries, data and new multimedia services of all sorts. As a result, and contrary to expectations and predictions, the telecommunications sectors all over the world did not witness any employment decline over the last decade, rather the contrary.

To compare the sectoral balance of gains and losses is therefore a difficult undertaking as numerous empirical studies of the 1980s and 1990s have shown. One certainty, however, is that an aggregate output growth which is substantially above productivity growth - as has been the case over the past few decades in a number of OECD countries, such as Denmark, Ireland, the Netherlands, the United Kingdom and the United States - will lead to significant declines in unemployment rates because the resulting employment growth is then sufficient to absorb both new labour-market entrants and displaced workers. As a matter of fact, the 1990s witnessed significant growth in labour force participation in these countries. This has been a source of additional growth in itself because many of the new entrants (women and young workers) display relatively high consumption levels, particularly in some of the new ICT areas (mobile communication, Internet use, etc.).

Why then are employment concerns about ICTs back at the top of the policy agenda, despite the many reassuring historical arguments, the macroeconomic success stories of the United States and some of the smaller European countries? A few of the reasons are outlined below. 
First, and implicit in the arguments set out above with respect to services, there is the particular impact of new ICTs on employment in the service sector, particularly in those services and occupations hitherto largely "protected" from automation or "informatization". In so far as such "sheltered" service employment has previously acted as the main absorber of employment displacement from manufacturing and agriculture, there is an obvious concern about whether new services will indeed be capable of providing sufficient new employment opportunities. As highlighted above, such new services are crucially dependent on an appropriate regulatory framework. Specifically, the emergence of new markets for information services requires not just a more competitive framework, deregulation and open access; it also requires new institutions setting out so to say the rules of such new markets, including those governing property rights, security, privacy, etc. At the same time, as the case of the Internet has shown, the speed of change can often outpace the old, "controlled" liberalization process pursued in many of the large, continental European countries and Japan. In some areas, such as finance and other intermediation services (public utilities), this might sometimes involve a more dramatic "creative destruction" process, with a completely new communication pricing structure. Particularly in Europe and Japan, there is concern that the regulatory reform is too slow and that the development of new services is lagging behind their development in other parts of the world.

Second, in so far as the dramatic decrease in the cost of obtaining data and information with new ICTs can be compared with a macroeconomic deflationary effect, the question is whether existing statistical methods for assessing "inflation" are still appropriate, and not increasingly measuring inflation "illusion" rather than the "traditional notion" of money illusion. It seems reasonable to assume that current European estimates of inflation - by ignoring many new products and services and many of the qualitative improvements typically associated with new ICTs - are overestimating inflation by 1 to 2 per cent a year. As a result, and as one might expect on the basis of the widespread diffusion of ICTs and the emerging information society, many European economies have suffered from the unduly strict monetary policies implemented within the framework of the EMU convergence criteria and following German reunification. The contrast between the relatively relaxed monetary policy of the United States Federal Reserve and that of the European Central Bank - at least until 1999 when the 2 per cent inflation target was formally launched - has been noted by many macroeconomists. This is not to deny the possible long-term positive impact of budgetary and fiscal consolidation policies on interest rates, private investment and employment growth - so-called crowding in - as argued by the European Commission. In the short term, however, the priority given to strict macroeconomic monetary policy during most of the 1990s has not been conducive to rapid emergence of the information society in Europe.

Third, since ICTs are "information" technologies — the essence of which consists of increased memorization and storage, speed, manipulation 
and interpretation of data and information - they have already "codified" large parts of human skills and will continue to do so. As emphasized in the previous section, this is not to deny the importance of the "tacit" part of knowledge. On the contrary, as more knowledge becomes codifiable, the remaining non-codifiable part is likely to become even more crucial. Thus, the ability to codify relevant knowledge in creative ways as well as the competence to sort out relevant information and to use it efficiently will assume ever-growing importance. By the same token though, an increasing number of routine tasks, even if they require a substantial amount of technically sophisticated skills, might become totally codifiable and see their importance dramatically reduced. ${ }^{13}$ As the largest part of employment in industrialized economies does involve such routine tasks, there is increasing concern about the distributional employment impact of the information society. Furthermore, given the accompanying widespread use of information and computer technologies, various skill, competence and qualification mismatches are likely to be of a much more pervasive and general nature, raising questions about the inherent "skill and competence bias" of new ICTs (Bresnahan, 1999). While these distributional concerns point to the crucial need for broadening education and training to benefit all groups in society, they also raise fundamental questions with respect to groups at risk of exclusion, such as unskilled, routine-task labour or "inactive", responsibility-averse employees.

Fourth, as a consequence of its potential for further international codification and transferability, ICTs can be considered as the first truly "global" technology. The capability of ICTs to codify information and knowledge over both distance and time not only brings about more global access, it also enables firms/organizations to relocate the sort of routine activities that can be codified and thus internationally traded. In other words, ICTs contribute to economic transparency and - in so far as it highlights the cost advantages of alternative locations - to international capital mobility and international "outsourcing" of particular activities. While the global benefits of this more transparent, borderless world are undisputed, there is again concern about the worldwide distribution of those benefits. For the poorest, most peripheral countries/regions there is concern about being excluded; for some of the industrialized, rich countries/regions, like Europe, there is concern about the increasing erosion of the monopoly rents associated with innovation and its implications for employment, wages and established social security systems. In most countries of the European Union, the financing of the national social security system and, more generally, that of the welfare state have been closely linked to employment, through contributions from both employers and employees. But in an increasingly global and economically transparent

${ }^{13}$ By contrast, it is interesting to observe that relatively "simple" human tasks (such as gardening) might never become codifiable. This explains why the idea of ICTs as "skill biased" technical change does not really capture the complexities of the de-skilling and reskilling processes involved (for more detail, see OECD, 1996). 
world, the national foundations of these systems are being undermined, raising fundamental questions about international competitiveness and/or the long-term sustainability of the national welfare system.

Fifth, and also with respect to Europe, while much has been written about the likely growth and employment impacts of EMU - including increased transparency in costs and prices, increased financial mobility, price stability and the crowding-in effect of private capital following fiscal consolidation induced by the so-called Maastricht criteria — little attention has been devoted to the likely impact of a set of radically new technologies such as ICTs on employment growth in the prospective single-currency area. The past decade suggests that European countries have not learnt much from each other's experience - an issue taken up in the next section.

\section{New labour-market policy challenges}

On the surface, the diversity of institutions and experiences actually appears to have limited Europe's endogenous capacity to gather sufficient macroeconomic growth momentum to reduce the very high unemployment rates of the 1980s. The strong inflation and mass unemployment that developed in the late 1970s and early 1980s were, from this perspective, symptoms and ultimately characteristics of a period of economic crisis. The timid institutional changes of the 1980s were motivated by the need to get out of that crisis. This led to structural adjustments - a key phrase in the 1980s aimed at reforming labour market institutions. Increasing the flexibility of labour markets therefore became a common policy objective.

Another field of reform - already discussed above and more typical of the late $1980 \mathrm{~s}$ - was linked to a more general concern to expand the sphere of "deregulated" market activities so as to take advantage of internationalization and the potential of ICTs that modified the time and space dimensions of economic activities. For all developed countries, the 1980s were an early phase in the diffusion of a new technological system centring on the new ICTs. Still, some countries were ahead and others lagged behind. ${ }^{14}$ The internationalization of most developed economies was under way, and international competitiveness was thought to depend strongly on mastering those new technologies.

Conscious of entering a period of transition, countries variously launched these two waves of institutional reform. While the deregulation of "regulated" services appears to have been a worldwide phenomenon that started in the early 1980s in the United States and the United Kingdom and spread progressively to the entire developed world over that decade, the need to deregulate labour markets was of particular concern to Europe.

${ }^{14}$ See, for example, the spread in the ratios of ICT investment expenditures to GDP over the 1980s as compared to the more recent period (OECD, 1999). 
The notion of "European sclerosis" developed in the early 1980s to account for the continuous rise of unemployment in Europe. This characterization was a partial view, however, omitting to consider the quality of the jobs created and the overall rates of employment which related to different lifestyles and traditions across Europe. Still, the debate itself was the expression of widespread pressure to reform the rules and practices of labour markets towards more flexibility in response to short-run changes in product markets, new patterns of organization (both within firms and across firms) and creation of a more active labour market. Change in the sectoral structure of employment did facilitate such transformations. The expansion of service activities, much less institutionalized than manufacturing activities, did help to achieve more flexible labour markets. This shift in the structure of employment was more open to new forms of work organization than were the largescale manufacturing activities, where labour was more organized and where more rigid practices constrained the organization of work, although they were under the strain of deregulation and the ensuing rearrangement of their production processes. By the end of the 1980s, labour market flexibility was the major issue on the policy agenda. ${ }^{15}$

Only in the late 1990s was the policy debate widened to a more general discussion on work, "non-work" and the status of work. While many of the concepts used are reminiscent of the 1960s, these debates are new and, in the final analysis, do not replicate those of the aftermath of the Second World War: most of the rich, OECD societies in which they are taking place now include more double-income families, living mostly in urban areas, with nearly three-quarters of them working in the service industry. The old debates and the choices made in the post-war period - especially regarding types of welfare systems - still influence today's options, but societies are now more affluent and more educated. Accordingly, the issues involved in redefining the status and content of work over each person's individual life cycle are now more centred around the kinds of training, the types of family structures preferred, the boundaries between public and private or personal and collective, and the division between work and non-work activities over one's life cycle (see KBS, 2000).

The role of education and training is certainly part of these deliberations, but again allowance must be made for the new context, one in which the supply of qualified labour has been substantially enlarged and the use of knowledge in economic activities extended, be it in its codified or tacit forms. Yet here too, the debate seems overly influenced by a vision centring on production processes, without taking account of personal needs and well-being. Thus, following the arguments set forth in the economics literature, the consideration of education and training has focused on two shifts that are inducing changes in their effective roles, namely the increase in the demand for

${ }^{15}$ See, for example, the early focus of The OECD Jobs Study on national unemployment and job creation issues (OECD, 1995). 
skilled labour and the abundant supply of qualified labour. Both developments obviously help to explain the increase in skill levels and, more generally, in the knowledge intensity of society. On the one hand, the debate about the presumed "skill bias" of technological change emphasizes the fact that firms have upgraded their skill requirements in order to face uncertainty about the evolution of production processes in times of rapid technological change and tense competition - once the direct effect of trade with low-wage countries has been scaled down to its relatively minor dimension (for a short survey of this issue, see Petit and Soete, 1999). On the other hand, studies have stressed that the supply of qualified labour has increased all over the developed world to such an extent that in some countries it has in itself reduced the number of jobs for the so-called "non-qualified" (Goux and Maurin, 1996; OECD, 1996, ch. 4).

By contrast, little has been said about two other major dimensions of the new challenge to education and training. One has to do with the social value of education and training both for participating in traditional social networks (conditioning family structuring, job opportunities, etc.) and for accessing new life patterns and taking advantage of complex new types of service provision (not only in health and education, but also in finance, transport, communication and distribution). From this perspective education and training also have to respond to new needs in economies in which relationships between producers and users have become essential knowledge links, with "smart" consumers as the final link in the chain. The other neglected dimension has to do with the laws of obsolescence of knowledge brought about by education and training. Recent work on literacy shows that the rate of obsolescence, as measured by comparing the effective capabilities of various education levels after several years, varies widely among countries (OECD, 1997).

These two issues raise questions about the content of education and training, the forms and channels through which they are provided and their timing along the life cycle. These questions are rather different from those raised in the post-war era when educational systems provided initial training of different kinds, giving access to specific professional trajectories more or less rigidly predetermined across countries. The advantages brought by education remain effective, but they are now more widespread and open to various upgrading opportunities and downgrading hazards encountered on the job. It follows that the meritocratic model, whereby positions were gained according to years of education, may not work as systematically and steadily as before. Rates of return to a given degree or course may vary widely, and it is not that easy to determine which curriculum to follow, especially since careers not only correspond to a wide range of wage trajectories but also increasingly include non-wage remuneraton (such as stock options or standard financial benefits).

As a matter of fact, with the new economic environment of the 1990s the question of wages and incentives has gained dramatically in importance. 
Individual countries have developed many practical ways of alleviating the fiscal levy on the highest incomes, developing new schemes for profitsharing, wage funds, and reducing minimum wages and thereby reducing their impact on demand for labour.

\section{Concluding remarks}

It is difficult to predict the precise employment impact of the new ICTs and the emerging information society, whether in terms of volume or of sectoral or occupational composition. Both direct and indirect employment effects are likely to be substantial and will undoubtedly further intensify the structural transformation of society. Thus, just as industries which barely existed before 1950 now employ millions of people - e.g. the software industry, the electronic computer industry itself, the microelectronic industry, the VCR and TV industries - today's emerging information and communication service sectors are providing new employment opportunities. However, the extent to which they will do so more rapidly will depend crucially on whether the regulatory institutional environment is conducive to the emergence of new information and communication markets and on the appropriateness of the macroeconomic climate. On both accounts the United States led the way over the 1990 s.

At the same time, there is - particularly in Europe - apprehension that both the direct and indirect employment-displacement effects of the information society will be substantial. Indeed, in some of the most typical information- and communication-dependent service sectors - such as finance, insurance and other business services - the efficiency-enhancing potential of the new ICTs is high. The number of jobs displaced, particularly among those of the routine kind, is expected to be high in those sectors. Furthermore, there is concern that many traditional, "non-tradable" service activities might become internationally tradable with the advent of the information society and that those activities will be relocated to low-wage countries or regions. Again, the jobs likely to be displaced are simple, routine-based jobs, not necessarily of the unskilled, manual type, but rather those in which the information or knowledge content appears most amenable to codification through ICTs.

Whether the net balance of these direct and indirect employment effects will ultimately be positive or negative cannot be assessed simply by counting new jobs gained and old jobs destroyed. On this point, what needs to be recognized is that the information society's expansionary effects on any national economy or on the world economy as a whole will paradoxically depend on how the new ICTs create the basis for a virtuous circle of growth in which investment is high and labour productivity grows fast, but output grows even faster, so that there remains net growth in employment. This is why one should remain fundamentally optimistic about the inherent, longterm welfare and employment opportunities associated with the emerging 
information society. However, such welfare gains and new opportunities cannot be taken for granted. Whether the virtuous circle can be sustained in Europe will depend on macroeconomic policies, regulatory and institutional reform in labour and product markets, more user-friendly and user-focused technology policies, new distributional policies, policies aimed at boosting productivity growth, as well as policies aimed at "integrating" the new ICTs in society. If there is a good match between technologies, policies and institutions, prolonged periods of full employment are much more likely to result.

Within the framework of the EMU, these developments raise new policy challenges directly related to various aspects of the economic use and organizational integration of new technologies, all of which are likely to have direct or indirect implications for employment creation at the level of the European Union and at local level, and all of which are likely to become crucially dependent on successful "skill matching" at those two levels. Two such challenges are likely to dominate the European policy debate in the years to come.

First and foremost, there is likely to be increased friction between regions and countries over demand for and supply of various categories of skilled labour. Particular regions are likely to experience increasing growth bottlenecks due to the local unavailability of particular skills, competences or knowledge. The lack of labour mobility across Europe is likely to be felt much more directly in a single-currency Europe than it has been in a freely trading single-market Europe.

Second, there is also a likelihood of greater productive capital mobility across Europe. Such mobility will increasingly become dependent on "real" factors such as the ratio of productivity to gross wage costs (unit labour costs) or the local availability of other crucial factors of production (e.g. skilled labour, qualified suppliers, infrastructure, etc.). In both cases the cost and availability of skilled labour will become crucial variables of "locational" advantage.

\section{References}

Aghion, Philippe; Howitt, Peter. 1992. "A model of growth through creative destruction", in Econometrica (Oxford), Vol. 60, No. 2, pp. 323-351.

Aronowitz, Stanley; DiFazio, William. 1994. The jobless future: Sci-tech and the dogma of work. Minneapolis, MN, University of Minnesota Press.

Bresnahan, Timothy F. 1999. "Computerization and wage dispersion: An analytical reinterpretation”, in Economic Journal (Oxford), Vol. 109, No. 456, pp. F390-415.

David, Paul A.; Foray, Dominique. 1995. "Accessing and expanding the science and technology knowledge base", in STI Review (Paris), No. 16, pp. 13-68.

Freeman, Christopher; Clark, John; Soete, Luc. 1982. Unemployment and technical innovation: A study of long waves and economic development. London, Pinter.

—; Soete, Luc. 1994. Work for all or mass unemployment? Computerised technical change into the twenty-first century. London, Pinter.

-; - 1993. Information technology and employment. Report prepared for IMB Europe. Maastricht, Datawyse. 
—; - 1985. Information technology and employment: An assessment. Brighton, University of Sussex.

Gershuny, Jonathan I. 1978. After industrial society? The emerging self-service economy. London, Macmillan.

—; Miles, Ian D. 1982. The new service economy: The transformation of employment in industrial societies. London, Pinter.

Goux, Dominique; Maurin, Eric. 1996. "Changes in the demand for skilled labour in France", in STI Review (Paris), No. 18, pp. 125-161.

Hansen, Alvin H. 1931. "Institutional frictions and technological unemployment", in Quarterly Journal of Economics (Cambridge, MA), Vol. 45, No. 4 (Aug.), pp. 684-697.

Jones, Charles I. 1999. "Growth: With or without scale effects", in American Economic Review (Nashville, TN), Vol. 89, No. 2 (May), pp. 139-144.

Katsoulacos, Yannis. 1984. "Production, innovation and employment", in European Economic Review (Amsterdam), Vol. 26, pp. 83-108.

KBS (Konig Boudewijn Stichting/Fondation Roi Baudouin). 2000. Travail et non-travail: vers la pleine participation. Brussels, Fondation Roi Baudouin, De Boeck Université.

Krugman, Paul; Venables, Anthony. 1994. Globalization and the inequality of nations. Discussion Paper CEPR No. 1015. London, Centre for Economic Policy Research. Sep.

Mankiw, N. Gregory. 1995. "The growth of nations", in Brookings Papers on Economic Activity (Washington, DC), No. 1, pp. 275-310.

Neisser, Hans P. 1942. “'Permanent' technological unemployment: 'Demand for commodities is not demand for labor'”, in American Economic Review (Ithaca, NY), Vol. 32, No. 1 (Mar.), pp. 50-71.

OECD. 2000. A new economy? The changing role of innovation and information technology in growth. Paris.

—.1999. OECD science, technology and industry scoreboard 1999: Benchmarking knowledgebased economies. Paris.

- 1997. Literacy skills for the knowledge society: Further results from the International Adult Literacy Survey (co-edited with Statistics Canada). Paris.

- 1996. The OECD Jobs Strategy: Technology, productivity and job creation. Two volumes. Paris.

- 1995. The OECD Jobs Study: Taxation, employment and unemployment. Paris.

- 1994a. The OECD Jobs Study: Evidence and explanations. Part I: Labour market trends and the underlying forces of change. Paris.

—.1994b. The OECD Jobs Study: Evidence and explanations. Part II: The adjustment potential of the labour market. Paris.

—. 1982. Micro-electronics, robotics and jobs. ICCP Series, No. 7. Paris.

Oliner, Stephen D.; Sichel, Daniel E. 2000. "Computers and output growth revisited: How big is the Puzzle?", in Brookings Papers on Economic Activity (Washington, DC), No. 2, pp. 273-334.

Petit, Pascal; Soete, Luc. Forthcoming. Technology and the future of European employment. Cheltenham, Edward Elgar.

—; - 1999. "Globalization in search of a future", in International Social Science Journal (Oxford), Vol. 50, No. 160 (June), pp. 165-181.

Pianta, Mario. 1995. "Technology isn't working: Review article”, in International Review of Applied Economics (Abingdon), Vol. 9, No. 3, pp. 366-371.

Porat, M.U. 1977. "The information economy”, in Definitions and Measurement (Washington, DC), Vol. 1-9.

Quinn, James Brian. 1986. The impacts of technology in the services sector. Paper presented to the Symposium on World Technologies and National Sovereignty, NAE Washington, 13-16 Feb.

Reati, Angelo. 1995. Radical innovations and long waves in Pasinetti's model of structural change: Output and employment. Economic Paper Series, No. 109. Brussels, European Commission, Directorate-General for Economic and Financial Affairs.

Rifkin, Jeremy. 1995. The end of work: The decline of the global labor force and the dawn of the post-market era. New York, NY, G.P. Putnam's Sons. 
Scarpetta, Stefano; Bassanini, Andrea; Pilat, Dirk; Schreyer, Paul. 2000. Economic growth in the OECD area: Recent trends at the aggregate and sectoral level. Economics Department Working Papers, No. 248. Paris, OECD.

Soete, Luc. 2001. "The challenges and the potential of the knowledge based economy in a globalized world", forthcoming in M. João Rodrigues (ed.): The new knowledge economy in Europe: A Strategy for international competitiveness and social cohesion. Cheltenham, Edward Elgar.

—. 1996. "The challenges of innovation", in Institute for Prospective Technological Studies (ed.): The IPTS Report. Sevilla, European Commission Joint Research Centre, No. 7, pp. 7-13.

- 1987. "The newly emerging information technology sector", in Christopher Freeman and Luc Soete (eds.): Technical change and full employment. Oxford, Blackwell, pp. 189-220.

—; Ter Weel, Bas. 1999. "Innovation, knowledge creation and technology policy in Europe", in De Economist, Vol. 147, No. 3.

Stoneman, Paul. 1984. An analytical framework for an economic perspective on the impact of new information technologies. ITEP-Project. Paris, OECD.

Turnovsky, Stephen J. 2000. Growth in an open economy: Some recent developments. National Bank of BelgiumWorking Paper No. 5. Brussels, NBB. May.

US National Commission. 1966. US National Commission on Technology, Automation and Economic Progress. Washington, DC.

Venables, Anthony J. 1985. "The economic implications of a discrete technical change", in Oxford Economic Papers (Oxford), Vol. 37, No. 2 (June), pp. 230-248.

Von Mises, Ludwig. 1936. Socialism. London, Jonathan Cape.

Weintraub, D. 1937. "Unemployment and increasing productivity", in National Resources Committee (ed.): Technological trends and national policy. Washington, DC, pp. 23-47.

Young, Alwyn. 1995. "The tyranny of numbers: Confronting the statistical realities of the East Asian growth experience", in Quarterly Journal of Economics (Cambridge, MA), Vol. 110, No. 3 (Aug.), pp. 641-680. 